\title{
The Gospel Roots of "Hawai'i Aloha"
}

\author{
RALPH THOMAS KAM
}

"Sweet are the notes he has woven in song."

-In Memoriam James McGranahan

"The Heavenly Father listens to the words rather than the tune."

—Ka Makua Laiana quoted in The Friend

Though many assume that the Reverend Lorenzo Lyons (18071886), known as Makua Laiana, wrote both the words and music of the iconic "Hawai'i Aloha," the song actually has two sources. While the Hawaiian lyrics were written by Lyons, a naturalized Hawaiian citizen, the popular tune was penned by American gospel hymn writer, James McGranahan (1840-1907). ${ }^{1}$

\section{LYRICS BY LORENZO LYONS}

The author of the lyrics, Lorenzo Lyons, (Figure 1) arrived in Hawai' $i$ on the whaling ship Averick on July 16, 1832, sent by the American Board of Commissioners for Foreign Missions in the Fifth Company of Protestant missionaries. A prolific writer of Hawaiian language hymns, Lyons has been called the "Dr. Watts of Hawai' $i$," comparing him to the Nonconformist minister, the Rev. Dr. Isaac Watts, considered by many to be the father of English hymnody. Indeed, it was

Ralph Thomas Kam holds an M.A. and a Ph.D. in American Studies from the University of Hawai 'i at Mānoa and a M.A. in Public Relations from the University of Southern California.

The Hawaiian Journal of History, vol. $5^{1}$ (2017) 


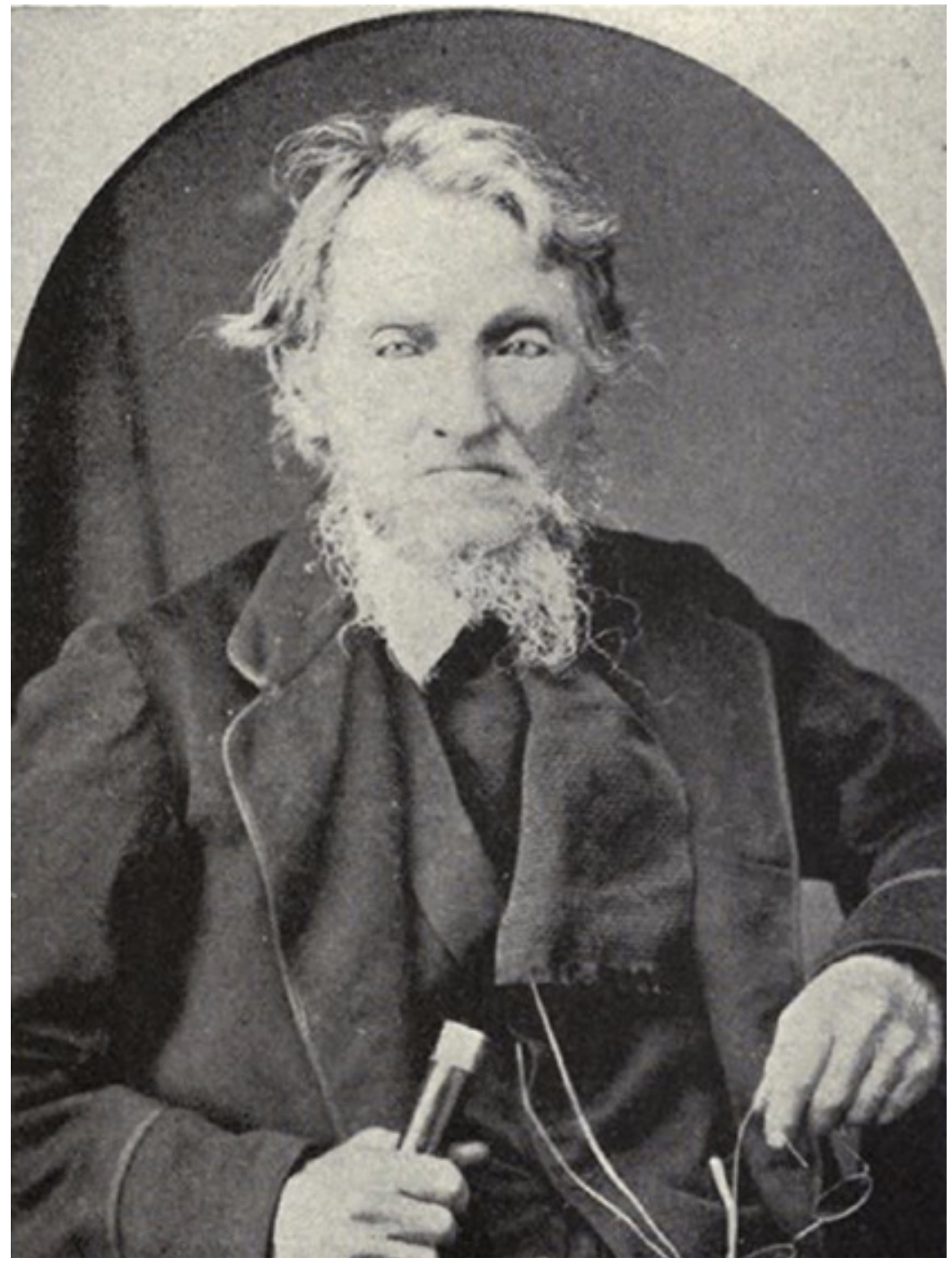

Figure 1. Lorenzo Lyons, also known as Makua Laiana, wrote the words for "Hawai' $\mathrm{i}$ Aloha." Public Domain, Portraits of American Protestant Missionaries to Hawaii (1901). 
a comparison that even Lyons did not dismiss. In his 1861 Waimea Mission report, Lyons wrote of Watts:

\begin{abstract}
Some brother advised me to wait till a Hawaiian Watts should arise \& give us thrilling strains of Hawaiian poetry-I waited till a Spirit seemed to pass by-perhaps it was that of the inimitable Watts himself-\& whispered as it were in my ear that there was no Watts before me-nor will there be one after me, go on \& do the best you can, have not the pride of thinking or attempting to equal me. In obedience to this whisper real or imaginary I have been going on with the work. ${ }^{2}$
\end{abstract}

With several hundred hymns written, translated or composed by Lyons, it is not surprising that he is given credit for both the words and the tune for "Hawai'i Aloha." Noted Hawaiian scholar, Samuel Hoyt Elbert, in Na Mele o Hawaii Nei: Io I Hawaiian Songs, wrote of "Hawai'i Aloha": "This is one of the many songs composed by the Reverend Lorenzo Lyons, known as Makua Laiana, who had a church for many years at Wai-mea, Hawaii. He died in 1886. A variant title for the song is Ku'u One Hānau. The song is so popular with Hawaiians that the melody is used in other songs."3 Elbert, making no distinction between the words and the tune, credits only Lyons.

Given that the song, "Hawai"i Aloha," was inducted into the Hawaiian Music Hall of Fame in 1998, it may seem strange today that Lyons did not include his most popular song in any of the hymnals he produced. Fortunately, the words to "Hawai'i Aloha" were preserved in the Hawaiian-language newspapers in the decades following his death. On December 11, 1886, a little more than two months after the death of Lyons, the Rev. Enoka Semaia Timoteo, pastor of the Waialua Hawaiian Church, wrote in Ka Nupepa Kuokoa:

Eia iho malalo nei ka olelo o ka Himeni mua i hakuia e ka Makua Rev. L. Laiana, mamua o kona hala ana. [Here below are the words of the foremost hymn composed by the Rev. Father L. Laiana, before his passing away.]

1.

E Hawaii-e, kuu one hanau-e

Kuu Home kulaiwi nei

Olino au i na pono lani ou

E Hawaii aloha-e 
Hui. E hauoli e na opio o Hawaii nei Oli-e, oli-e

Mai na aheahe makani e pa mai nei

Mau ke aloha no Hawaii.

2.

E hai mai i kou mau kini lani-e

Kou mau kupa aloha e Hawaii

Na mea olino kamahao no luna mai

E Hawaii aloha-e

Hui. E hauoli \&c.

3 .

Na ke Akua e malama mai ia oe

Kou mau kualono aloha nei

Kou mau kahawai olinolino ou

Kou mau mala pua-e.

Hui. E hauoli \&c.

The first and third verses along with the refrain, with different words at the end of line two of the first verse and the first line of the chorus, appeared in the November 1 1, 1899, edition of Ke Aloha Aina:

1-E Hawaii e kuu one hanau e,

Kuu home kulaiwi nei,

Oli no au i na pono nani ou,

E Hawaii aloha e,

Cho.-E hauoli e na kupa o Hawaii

Oli e, Oli e.

Mai na aheahe makani e pa mai nei

Mau ke aloha no Hawaii.

2-Na ke Akua e malama mai ia oe,

Kou mau kualono aloha e,

Kou mau kahawai olinolino ao,

Kou mau mala pua nani e.

Although the lyrics have been preserved, some words have been joined, "Olino" instead of "Oli no" in the third line of the first stanza, and some lines have differed from version to version, especially the 
third line of the second stanza, which ended in the word, "ou," in 1886, "au" in 1899 , and "mau" in the years following.

The first full printing of the lyrics by Lyons in a hymnal came in 1924, when the words, but not the tune, appeared as hymn 222 in $\mathrm{Na}$ Mele o Ziona, a Hawaiian-language songbook of the Church of Jesus Christ of Latter-day Saints. The committee overseeing the production of the hymnal included Clarence Kinney and Akiona Kauka, who made many of the translations, and George P. Mossman, an ukulele manufacturer. The preface for the hymnbook recalled the purpose of efforts that began in the late 1880 : "The poetic language of the people may thus be preserved in hymns of praise and adoration." Ethel Moseley Damon, a Protestant missionary descendant, praised the Mormons for conservation of hymns by Lyons in The Friend in May 1935. The Mormon hymnals, she wrote,

still include several of Laiana's favorite old hymns with due credit accorded him. Indeed for the preservation of one his most beautiful Hawaiian songs we have largely to thank the devotion of Mormon communities, for it is among their older people that we have at last been able to find more than the memory of Laiana's Hawaii Aloha, My Home, My Native Land. This is his young people's ode sung to the old tune of the gospel hymn, I Left It All With Jesus, but apparently never printed as a Hawaiian hymn. ${ }^{5}$

All told, 15 of the 222 translations in the Mormon songbook are credited to Lyons. Only the first 212 hymns, though, included music; the last ten, including "Hawai'i Aloha," have only the words of the hymns. Since no tune appeared with "Hawai'i Aloha," James McGranahan did not receive credit for the music. He was, however, recognized for two other tunes in Na Mele o Ziona: hymn No. 15, "Mahope Hoomaopopo Ai ("Sometime We'll Understand," words by Presbyterian minister, Maxwell N. Cornelius; translated by Mormon elder, Clarence W. Kinney) and hymn No. 212 , "Ko’u Makua Ma Ka Lani” (“O My Father,” a classic Mormon hymn written by Eliza Snow, wife of Brigham Young).

\section{Music by James MaGranahan}

The music for "Hawai'i Aloha" was written by James McGranahan, (Figure 2) who unlike Lyons, had never visited Hawai'i. McGranahan 


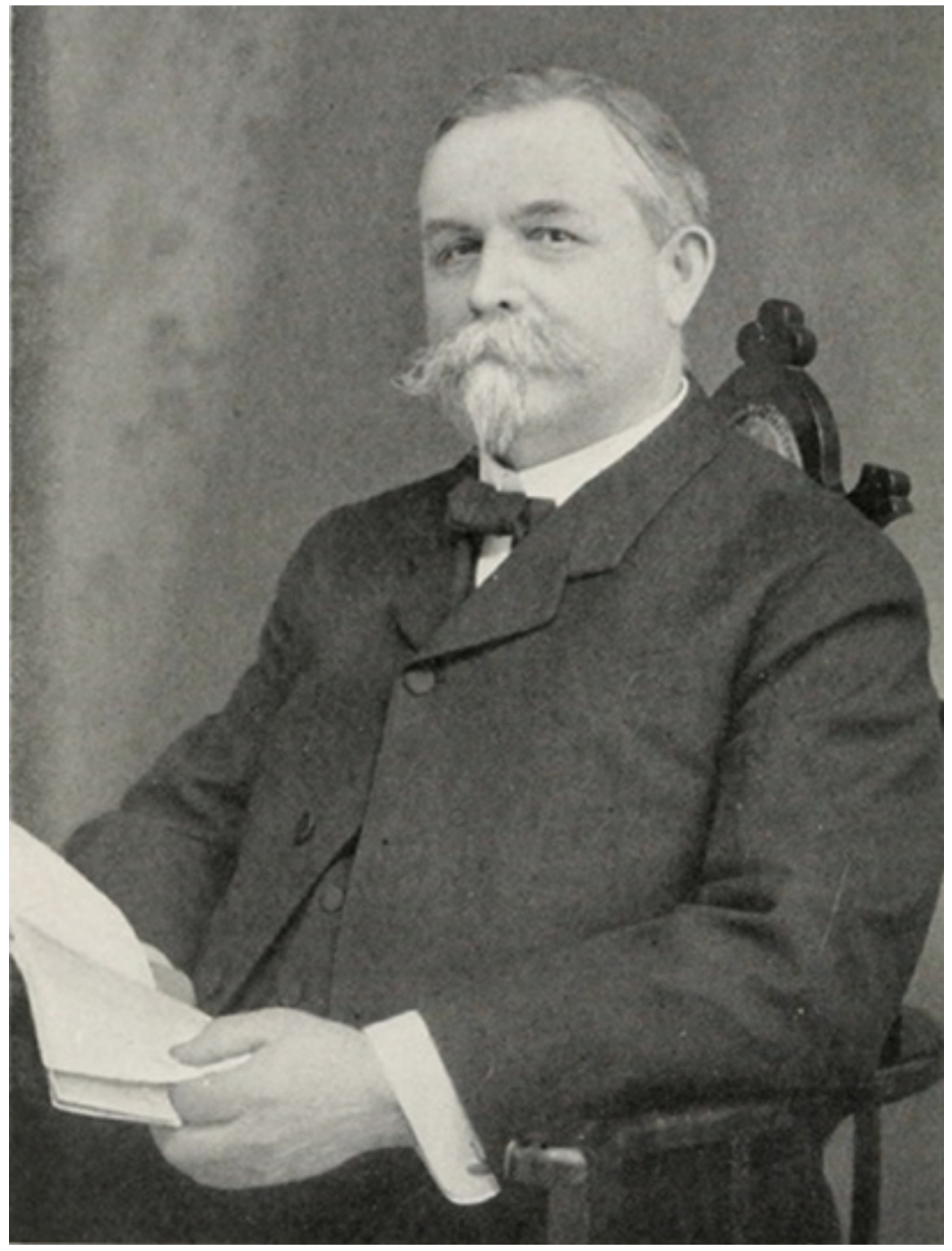

Figure 2. James McGranahan composed the tune called "I Left It All With Jesus," which Lyons used for "Hawai'i Aloha." Public Domain, From James McGranahan (1907). 


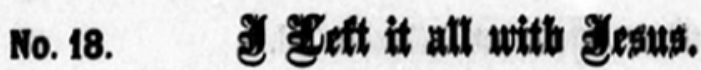

"Canting all jour care upon bim, for bo careth for you."-1 Per. 5: 7.
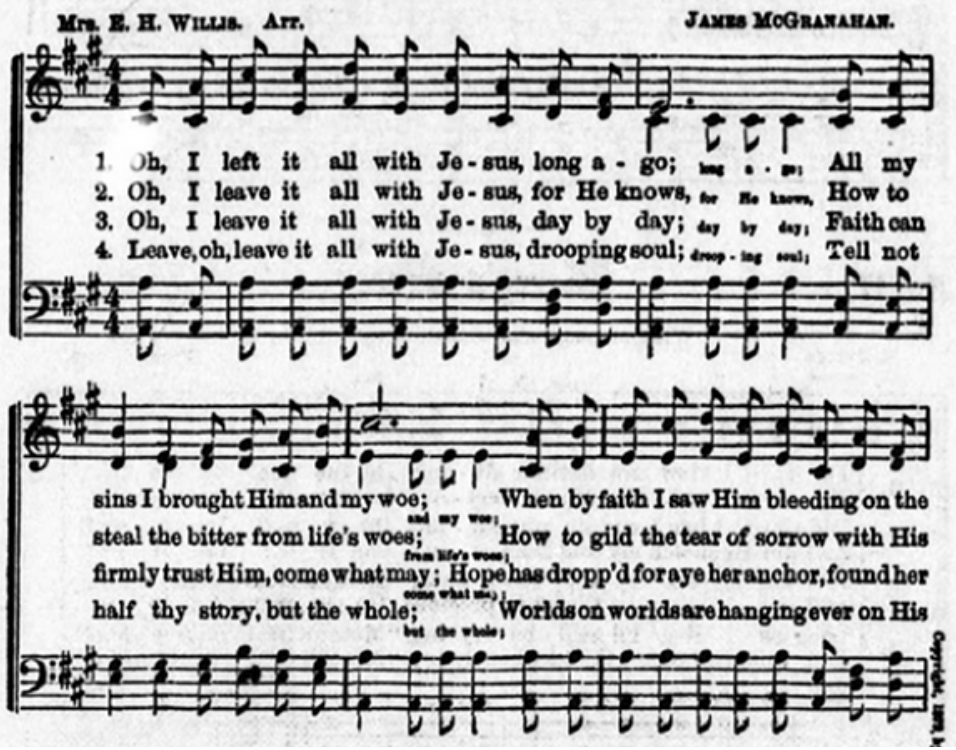

Figure 3. The 1886 reference in Ka Nupepa Kuokoa to "G.H. IV No. 18 " indicated hymn 18 in Gospel Hymns, No. 4. The familiar echo of the last words of the lines has been retained in "Hawai'i Aloha." Public Domain, Gospel Hymns, No. 4. (1886).

was born more than 4,8 oo miles to the east in West Fallowfield Township, Pennsylvania, on July 4, 1840. The tune for "Hawai'i Aloha," instead, traveled to Hawai'i in written form. The first published link between "Hawai“i Aloha" and the music by James McGranahan appears in Ka Nupepa Kuokoa in December 11, 1886, when the Rev. Timoteo lists the first line of the song and an abbreviation of the title of the hymnal and hymn number for the tune:

1. "E Hawaii e kuu one hanau-e"

G. H. IV. No. $18^{6}$

The cryptic abbreviation, “G. H. IV. No. 18," refers to hymn 18 in Gospel Hymns, No. 4, published in 1881 . Hymn 18 is titled "I Left it all with 
Jesus," with music by James McGranahan. ${ }^{7}$ (Figure 3). The attribution of the tune is beyond doubt as the hymnal was edited by Ira David Sankey, James McGranahan and George Coles Stebbins. The hymn was later included in the 1894 compilation titled Gospel Hymns Nos. 1 to 6 Complete (Without Duplicates) as hymn 2o6. A copy of the same 1894 edition in the collection of the Hawaiian Mission Children's Society, given to the organization's archive by Ethel Damon in 1959, includes a pencil inscription on the front end sheet: "Melody to Hawaii Aloha "I Left it All With Jesus" pg. 206."

The title, "I Left It All With Jesus," is derived from the first line of the poem by Ellen H. Willis. The words of her poem appeared in 1843 as hymn 399 in First Truths; or, Lessons and Hymns for Christian Children. New edition, published the Society for Christian Knowledge, an Anglican mission organization. The hymnal credits no author and lists the meter as P.M. or Peculiar Meter. The hymnal includes only words with no recommended tune. Hymn 399 reads:

I LEFT it all with Jesus long ago;

All my sin I brought Him, and my woe.

When by faith I saw Him on the tree, Heard His still small whisper, "Tis for thee,"

From my heart the burden rolled away-

Happy day!

I leave it all with Jesus; for He knows

How to steal the bitter from life's woes,

How to gild the teardrop with his smile,

Make the desert garden bloom awhile.

When my weakness leaneth on His might, All seems light.

I leave it all with Jesus day by day:

Faith can firmly trust Him, come what may.

Hope has dropped her anchor, found her rest

In the calm, sure haven of His breast:

Love esteems it heaven to abide

At His side.

Oh, leave it all with Jesus, drooping soul!

Tell not half thy story, but the whole. 
Worlds on worlds are hanging on His hand,

Life and death are waiting His command;

Yet His tender bosom makes thee room:

Oh come home! ${ }^{9}$

The words for "I Left It All With Jesus," credited to "Miss Ellen H. Willis," appeared in Gospel Hymns and Sacred Songs (1875) as hymn No. 9o. The tune, attributed only as "English," is in Peculiar Meter, 10.9.9.9. with a refrain of 9.3. The numbers indicate the syllables per line (ten in the first line of the stanza, nine in the second, third, and fourth lines; nine in the first line of the refrain, three in the second).

The words by Ellen $\mathrm{H}$. Willis also appear under her name in a collection of her poems published more than three decades after "I Left It All With Jesus" first appeared in print. Willis wrote a preface to I Left It All with Jesus, and Other Poems at Hampstead, England, in October 1875 :

It has long been the wish of the Author's friends, that the following poems, many of which have already appeared in different publications, should be gathered together in one volume. She therefore, with much diffidence, presents them to the public, trusting that the favour and indulgence which some have received will be extended to all, and that the blessing of God will accompany them and His Spirit use them for His glory! ${ }^{10}$

The words of her poem are the same as words of hymn 399 in First Truths; or, Lessons and Hymns for Christian Children. New edition (1843) and hymn No. go in Gospel Hymns and Sacred Songs (1875). With the 1875 publication of her poems, Willis makes an undeniable claim to the authorship of the lyrics first printed anonymously more than three decades prior.

A major transformation occurred when "I Left It All With Jesus" appeared in Gospel Hymns, No. 4 (1881); the meter changed from 10.9.9.9 with a refrain of 9.3. to 11.9 .11 .9 , with a refrain of 11.6 . The change required one additional syllable in first line, two additional syllables in the third line, two more in the first line of the refrain and three more in the second line of the refrain. The new lyrics below show added syllables in italics and omitted words struck out: 
$O h$, I left it all with Jesus, long ago;

All my sins I brought Him, and my woe.

When by faith I saw Him bleeding on the tree,

Heard His still small whisper, "Tis for thee,"

From my weary heart the burden rolled away-

Happy day! Happy day!

Oh, I leave it all with Jesus; for He knows

How to steal the bitter from life's woes,

How to gild the teardrop tear of sorrow with His smile,

Make the desert garden bloom awhile.

When Then with all my weakness teaneth leaning on His might,

All seems is light! all is light!

$O h$, I leave it all with Jesus day by day:

Faith can firmly trust Him, come what may.

Hope has tropped dropp'd for aye her anchor, found her rest

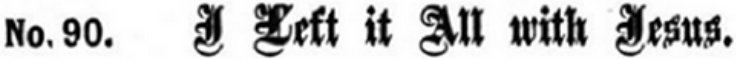

"Casting all your care upon Him; for He careth for you."-1 Perks 5: 7.

Miss Elu.sx H. Wruss.

Engliah.
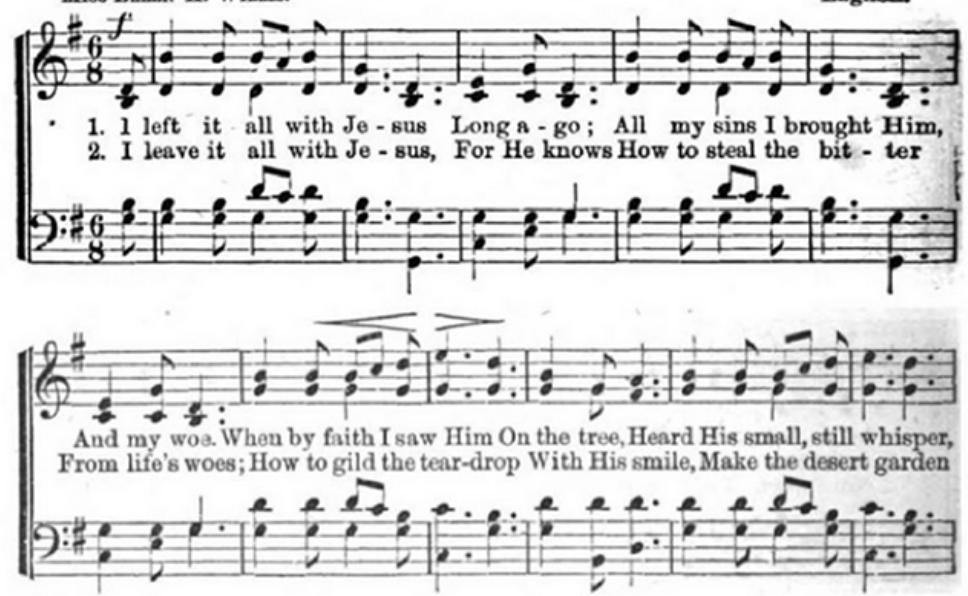

FIgURE 4. Ellen H. Willis finally received credit for the words of "I Left it All With Jesus" in 1875 . The tune is not the one used for "Hawai i Aloha." Public Domain, Gospel Hymns and Sacred Songs (1875). 
In the calm, sure haven of His breast:

Love esteems it joy of heaven to abide

At His side! At His side!

Oh, Leave, oh, leave it all with Jesus, drooping soul!

Tell not half thy story, but the whole.

Worlds on worlds are hanging ever on His hand,

Life and death are waiting His command;

Yet His tender bosom loving mercy makes thee room:

Oh come home! Oh, come home!

The modified Willis lyrics and McGranahan tune continued to be published together, even after the composer's death in 1907, as hymn 44 in Alexander's Gospel Songs No. 2 (1910) and hymn 93 in Northfield Hymnal No. 3 (1918). Although the tune by McGranahan is called "I Left It All With Jesus," it more appropriately should be called "Oh, I Left It All With Jesus" to distinguish it from previous tunes. Miss H.M. Warner composed a different tune for the lyrics by Willis that were published in 1875 in Gospel Hymns and Sacred Songs (Figure 4). It was the tune by McGranahan printed in 1881 , however, which was used for "Hawai'i Aloha."

\section{Words by Lyons, Tune by McGranahan}

Although they had been previously published separately elsewhere, the first printing of the words of "Hawai'i Aloha" by Lorenzo Lyons and the tune by James McGranahan (but not his name) appear together on the same page in the children's songbook called Simple Songs for Little Singers (1931). Damon attributed the continued popularity of "Hawai'i Aloha" to its inclusion in the book: "It is one of the best-loved among the older folk and the younger ones are now singing it with the same affection, its renaissance due in large measure to the patient search and enthusiastic stimulus given by one of our most gifted educators, Miss Jane Lathrop Winne."11 When Damon reprinted her article in booklet form she added: "Name and source for the original tune were given us by Mrs. Melia Kaiawe of Lihue, Kauai."12 It was Winne, a great-granddaughter of Asa Thurston, who put together the revision of an earlier edition of the book by Anna B. Tucker. Winne wrote in the forward to the second edition: "The 
entire last section 'Songs of Our Playmates' is new, many of the number appearing for the first time in printed musical form." 13 Among the inaugural printings in the section was "Hawai'i Aloha," its words attributed to "Rev. Lorenzo Lyons" and music to "Hymn Tune." 14 The song was one of eight Hawaiian-language songs included in the book. The 1969 edition of the Missionary Album related: "Miss Jane Winne, wishing to include it ["Hawai"i Aloha"] in this book [Simple Songs for Little Singers], prevailed upon some elderly Hawaiians to sing this old favorite that had almost been forgotten. She was obliged to take down the melody by ear and harmonize an accompaniment." 15 The aural transcription of the song may have resulted in the shift from a meter of 11.9.11.9 to the current 11.9.11.8, dropping one syllable from the fourth line of the stanza.

The tempo of "Hawai'i Aloha" has also changed over time. Historian David Forbes shared his conversation with a granddaughter of Lyons regarding the original tempo of "Hawai'i Aloha." She said that the Sunday school hymn was meant to be sung at a joyful clip, unlike the slowly paced renditions of today.

The second songbook to include the words by Lyons and tune by McGranahan, the Protestant hymnal titled Leo Hoonani Hou (1953), credited "Rev. Lorenzo Lyons" with the authorship of "Hawai"i Aloha," and like Simple Songs for Little Singers, attributed the music to a "Hymn Tune." 16

Although the tune of McGranahan and words of Lyons were printed together in songbooks published in 1931 and 1953, the music composer's name did not appear with "Hawai'i Aloha" until 1972. (Figure 5) That year, more than nine decades after the tune was written, Na Himeni Haipule Hawaii rightly listed James McGranahan as the composer of the music, which it titled "Laiana," with a meter of 11.9.11.8. In 1979, George S. Kanahele, founder of the Hawaiian Music Foundation, in his Hawaiian Music and Musicians clearly assigned credit: "The words are set to an old hymn tune, "I Left It All with Jesus," composed by James McGranahan (1840-1907)." J7 John Berger, who edited the revised edition of Kanahele's book, repeated the connection in Hawaii Magazine in 1996 when he quoted a prominent local musician:

"Lyons is often given credit for both the lyrics and melody, but he wrote it to (the music of) 'I Left It All With Jesus' by James McGranahan, 
who was a contemporary of his," explains kamaaina composer and performer Keith Haugen. ${ }^{18}$

Despite the assignment of credit to McGranahan in a major Hawaiian-language hymnal and one of the most comprehensive books on Hawaiian music, his name was omitted in another widely used publication. In 1985, "Makua Laiana (Rev. Lorenzo Lyons)" once again received credit for both the words and music in the Hawaiian Studies Curriculum Guide, Grade 3, published by the State of Hawai'i Department of Education. ${ }^{19}$ The curriculum included music transcribed by University of Hawai'i music professor, Byron Yasui, and an English translation by Mrs. Mary Kawena Pukui and Mrs. Lucy Kalanikiekie Henriques.

\section{English TransLations}

Though originally composed in Hawaiian for Hawaiian-language songbooks and hymnals, three English translations have been completed for "Hawai'i Aloha." Ethel Damon quoted the first version in an article about Lyons in the June 1932 edition of The Friend. She wrote of the song: "Its English version has been set down recently by Mrs. Mary Pukui and Mrs. Kalani Henriques:

Hawaii Aloha-Translation

O Hawaii, land of my birth.

My home, my native land,

Sing I of thy heavenly righteousness,

Hawaii, aloha.

Chorus:

Be joyful, youth of Hawaii,

Sing! Sing!

On the gentle zephyrs is wafted

Hawaii's aloha forever.

Reveal, O heavenly hosts,

To the beloved sons of Hawaii

The bright wonders from above,

O Hawaii, aloha. 

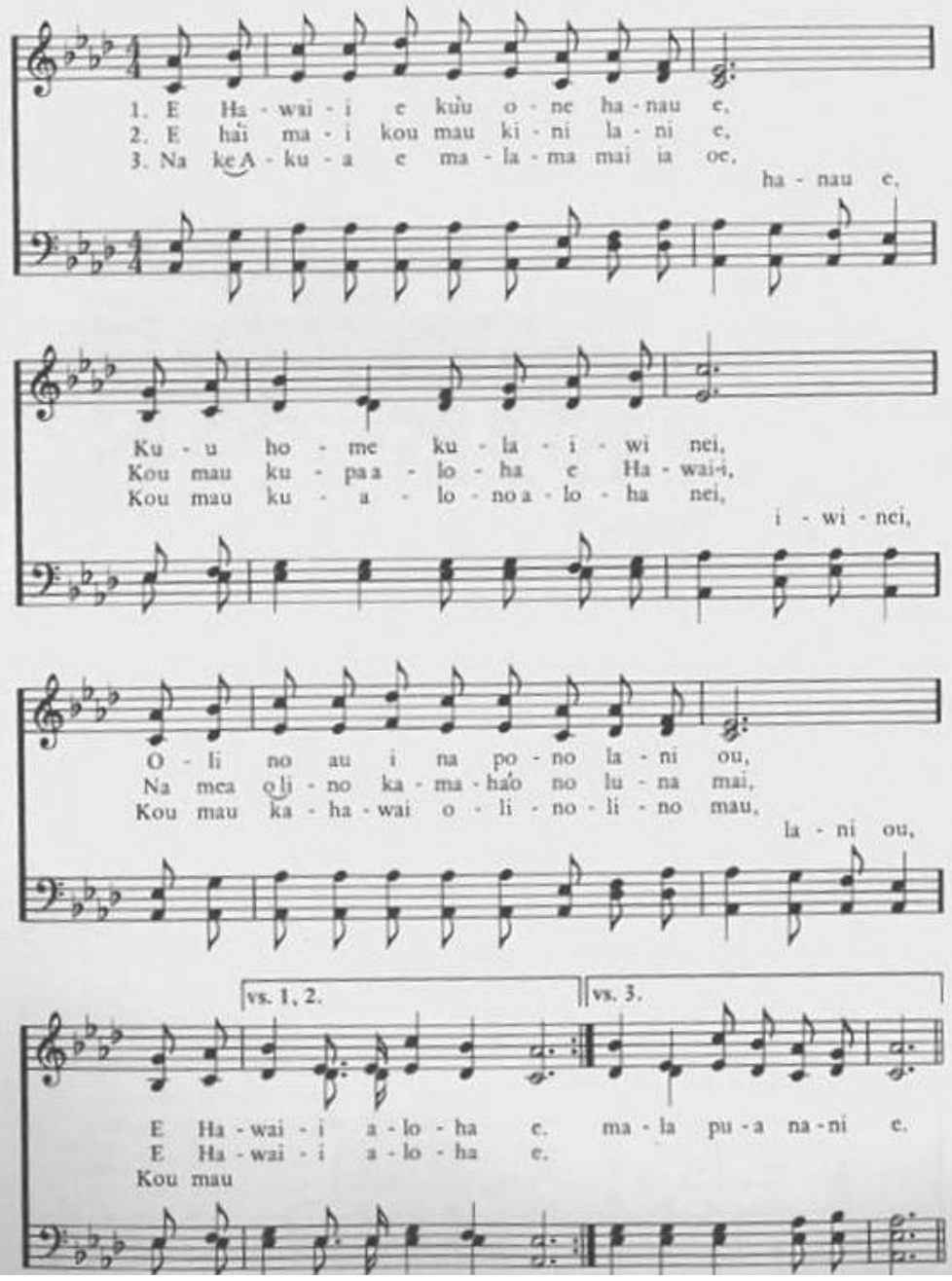

Figure 5. The name of James McGranahan does not appear on sheet music for "Hawai' 'i Aloha" until 1972 in Na Himeni Haipule Hawaii. Copyright 1972 by the Hawai' $\mathrm{i}$ Conference United Church of Christ. Used by permission. 

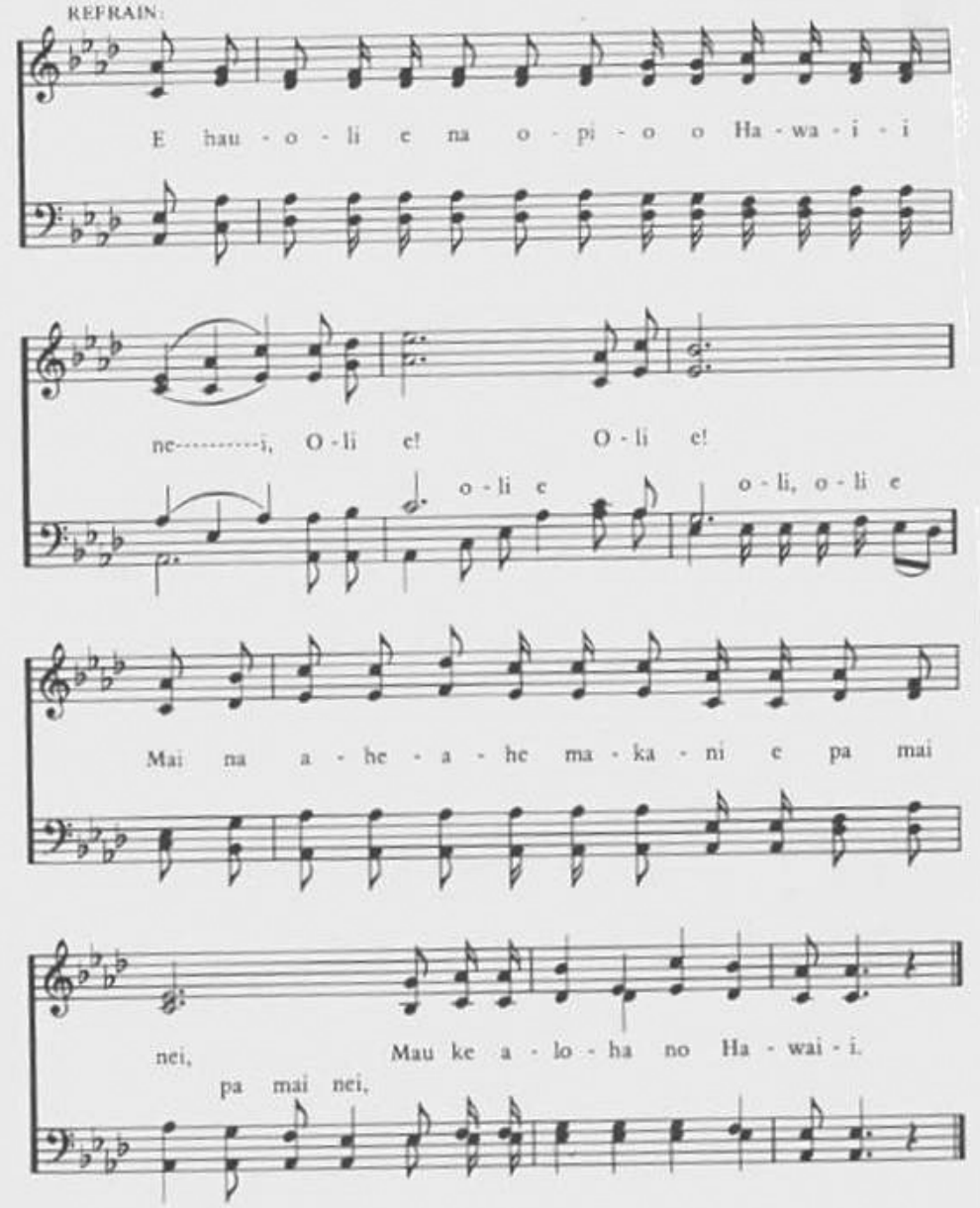

O Hawaii, my own birthplace, my own land,

Our dear islands, long as mountains stand,

I will sing of truth and justice, heavenly peace.

I will sing of Hawaii Nei!

Hawaii's youth now raise your voices, $\mathrm{O}$ Hawaii Nei!

This glad day! This glad day!

While the gentle winds are wafted o'er God's blue sea,

I will sing of our Hawaii! 
The Lord will protect you,

Your loved hills and valleys,

Your sparkling streams,

Your beautiful garden of flowers. ${ }^{20}$

The same English translation also appeared after each Hawaiian line in the 1931 edition of Simple Songs for Little Singers without specific identification of the translators of "Hawai'i Aloha," ${ }^{21}$ who instead received general credit by name with all of the translators in the book's forward. ${ }^{22}$

The second English translation, was published in 1970 in Nā Mele o Hawai'i Nei: Iо I Hawaiian Songs by Samuel Hoyt Elbert, presumably by the author. It reads:

O Hawaii, O sands of my birth, My native home,

I rejoice in the blessings of heaven.

O Hawaii, aloha.

Chorus

Happy youth of Hawaii

Rejoice! Rejoice!

Gentle breezes blow

Love always for Hawaii.

May your divine throngs speak,

Your loving people, O Hawaii.

The holy light from above.

O Hawaii, aloha.

God protects you,

Your beloved ridges,

Your ever glistening streams,

Your beautiful flower gardens. ${ }^{23}$

The third English translation, which can actually be sung to the McGranahan tune, was the work of Annie Kanahele and Edith Wolfe. The first verse and chorus appeared in 1972 in Na Himeni Haipule Hawaii: 
O Hawaii, my own birthplace, my own land

Our dear islands, long as mountains stand, I will sing of truth and justice, heavenly peace

I will sing of Hawaii Nei!

Hawaii's youth now raise your voices, O Hawaii Nei!

This glad day! This glad day!

While the gentle winds are wafted o'er God's blue sea.

I will sing of our Hawaii! ${ }^{24}$

Kanahele and Wolfe were both members of the Hawaiian Hymnbook Committee that oversaw the publication $\mathrm{Na}$ Himeni Haipule Hawaii (1972). The subsequent 1999 edition of $\mathrm{Na}$ Himeni O Ka Ekalesia included "Hawai'i Aloha" as hymn 135 but dropped its English translation.

Just two lines are translated in another 1972 publication, Native Planters in Old Hawaii, by E. S. Handy, E. G. Handy, and Mary Kawena Pukui. Despite having an existing English translation by Pukui and Henriques, the book included the following: "An old song has the line: E Hawaii e, ku'u one hanau e, ku'u home kula iwi nei; 'O Hawaii, soil of my birth, my own home where my bones belong to the plains." 25 The 1931 translation by Pukui and Henriques of the same two lines read: "O Hawaii, land of my birth. My home, my native land." ${ }^{26}$

\section{Origins of "Hawai'i Aloha”}

Lacking a dated, handwritten poem by Lyons, the origin of the popular song has been subject to widespread speculation. The earliest supposed date for composition, $185^{2}$, appears in Hawaiian Music and Musicians: An Illustrated History (1979). Although the editor of the volume, George S. Kanahele, confessed that he was "uncertain about the hymn's origins," he, nevertheless, repeated earlier assumptions about when it was written: ${ }^{27}$ "According to Ethel Damon (1935), Lyons may have composed the song in 1852 on the occasion of the departure of the first company of Hawaiian missionaries to the South Pacific." 28 Kanahele and John Berger retained the reference to the $185^{2}$ date in their revised book, Hawaiian Music $\mathcal{E}^{\circ}$ Musicians: An Encyclopedic History (2012), but admitted that "the origins of the song as it is known 
today are speculative at best." 29 The date for the tune's composition is probably too early, given that the composer of the tune, James McGranahan, was born July 4, 1840, making him twelve years old in 1852 . Berger, writing in Hawaii Magazine in 1996, avoided specifying an exact date, simply writing that the lyrics "were written more than 100 years ago." 30

The reference by Kanahele to $185^{2}$ as the year of composition may be drawn from the 1953 edition of Makua Laiana in which Emma Lyons Doyle adds a couple of paragraphs in the middle of a reprint of portions of a 1932 article by Ethel Damon. The added material, absent from the 1945 edition of Makua Laiana, ${ }^{31}$ reads:

A newspaper account of the day describes the ceremonies that took place at the departure of the first company of Hawaiian missionaries for the South Sea Islands. It tells of the "singing in Hawaiian of 'Yes, My Native Land I Love You', a translation made for the occasion by the Reverend Lorenzo Lyons.

$[\ldots]$

It has been suggested that the arrangement mentioned was perhaps "Hawaii Aloha". However, though "Hawaii Aloha" too is the song of a native land, its words are certainly not a translation of the English words quoted in the newspaper account, and the English words cannot be fitted into its melody." 32

Set in the middle of material from Damon, the words do not appear to have been written by her. The positioning of a comma and periods after the final quotation mark are inconsistent with the usual punctuation practice by Damon. A misinterpretation of the phrase, "first company of Hawaiian missionaries for the South Sea Islands," may have led to the erroneous date of $185^{2}$. American missionaries did travel to the South Pacific in 1852. The Rev. Luther Halsey Gulick and Louisa Mitchell Lewis Gulick left Hawai'i on July 15, 1852, arriving in Ponape on September 1 1, 1852. The couple, however, did not constitute a company. The account of Lyons translation of "Yes, My Native Land I Love Thee," is instead linked to the voyage of John Fawcett Pogue, who departed for Micronesia on July 8, 1869, with a company of nine other missionaries. The Pacific Commercial Advertiser reported about a meeting at Kaumakapili Church, the day before 
they left: "During the meeting the company of missionaries and their wives, ten in all, stood up and sang for the first time in Hawaiian the beautiful hymn commencing

"Yes my native land I love thee,

All the scenes I love them well,"

which has recently been translated by Rev. L. Lyons."33 That the aforementioned hymn is not "Hawai"i Aloha" is absolutely certain, because Lyons included his translation of "Yes, my native land, I love thee" as Hymn 480 in Ka Buke Himeni Hawaii (1872). The first stanza of the hymn, with a meter of 8.7. , reads:

1. Aloha au la i kuu aina,

I kuu aina hanau nei,

Na makua, me na kini

O na hoa makamae;

Hiki anei ke haalele

Ia oukou a hele ae? ${ }^{34}$

He Mele Aloha (2003) ventured that Lyons "wrote the words originally as a poem around 1860," and that "they were later set to the music of I Left It All With Jesus." "35 Although no source is given in $\mathrm{He}$ Mele Aloha for the supposed date of composition, Lyons was certainly writing poems that year. In January 1860, Lyons wrote in his Waimea Mission Report: "Being somewhat confined to the house by bodily infirmity, I have devoted time to writing hymns. Quite a transition from building meeting houses to writing poetry!" 36 It is improbable, however, that the words were later set to the music; the meter of the music, 11.9.11.9, is called Peculiar Meter (P.M.) in some hymnals because of the irregular number of syllables per line. Though not impossible, finding a tune with such an uncommon meter to match a poem written in same odd meter would have been quite unlikely. It is more probable that Lyons wrote the words to agree with the meter of the tune. If so, Lyons probably only had access to the tune by McGranahan after its publication in Gospel Hymns No. 4 in 1881 or possibly in sheet music or a tune book that accompanied Gospel 
Hymns, No. 4 (Words Only) in $1879 \cdot{ }^{37}$ All earlier versions of the music for "I Left It All With Jesus," set to music by other composers, had a different meter (10.9.9.9) than "Hawai'i Aloha."

The Missionary Album, published for the sesquicentennial commemoration of the arrival in Hawai' $i$ of the First Company of the ABCFM missionaries, estimated that hymn tune "I Left It All With Jesus" was "written by James McGranahan about $1879 . " 38$ That date agrees with the publication of Gospel Hymns, No. 4 (Words Only) in 1879.

Conjecture also abounds regarding the motive behind the composition of the popular piece. The Missionary Album concluded that "Hawai'i Aloha" was "probably written on the occasion of a special event," ${ }^{39}$ though it did not name the event. One website claims that Kamehameha IV asked Lyons to write Hawaiian words for the tune, ${ }^{40}$ an oft repeated story. Another website expands on the tale: "The tune came from McGranahan's hymn 'I left it all with Jesus' and this hymn just so happened to be King Kamehameha IV's favorite song. Kamehameha then asked Lyon to write a new song using the tune and Hawai'i Aloha was created." ${ }^{11}$ In another online variation, the hymn is commissioned for religious purposes: "In the midst of traumatic changes to the life of the Hawaiian people in the latter part of the 19th century, King Kamehameha IV asked missionary Lorenzo Lyons (Makua Laiana ... Father Lyons) to adapt an English hymn 'I Left It All With Jesus' (written in the 1840 's by James McGranahan) for the Hawaiian churches." ${ }^{42}$ Since Kamehameha IV died on November 30 , 1863, and the American tune by McGranahan appeared in print in 1879 or 1881 , the song could not have been the king's favorite song.

Damon, in her extensive study of Hawaiian language hymns, may have provided an important clue to the origin of "Hawai'i Aloha" when she wrote in April 1935 about the source of some of the translations by Lyons in the 188 os: "Also, not many years before he died, Laiana issued a number of Moody and Sankey gospel hymns in small booklets of several editions which Dr. Hyde states met with speedy sale and were largely responsible for the success of revival meetings in 1881 and 1882." ${ }^{43}$ Dr. Charles McEwen Hyde had been sent to Hawai' $i$ by the American Board of Commissioners for Foreign Missions in 1877 .

Ira David Sankey served as musical director for the evangelical meetings conducted by Dwight Lyman Moody. Along with Philip Paul 
Bliss, Sankey published Gospel Hymns and Sacred Songs in 1875, one of the first songbooks to attach the name of Willis to her lyrics. The hymn, "I Left It All With Jesus," albeit not one set to the McGranahan tune, was included as No. go in that volume. Hymn No. go would later be translated into Hawaiian in a set of three booklets bound together as Na Himeni Euanelio: I Unuhiia e L. Laiana Mamuli o Moody me Sankey, etc., which was published in 1886 . In the words-only songbook, "I Left it All With Jesus" was translated by Lyons as hymn 25, titled "Ua Waihoia Ia Iesu," in the third set, Buke III or Book III:

1. Ua waihoi $a$ ia Iesu.

Mamu $a$ no

Kuu mau lawehala, Kuu luuluu.

Iaia ma ke kea, Nana mai.

A hawanawana.

Nou no nei.

II: Kaa ae mai o'u aku

Kuu luu, maha au. : : :I

2. Ua waihoi $a$ ia Iesu.

Kuu haalou

No ka paumaele,

Mihi no.

Nana $e$ hoohauoli,

Oli au.

Nana e hoomalu,

Malu no.

II: A kapeke au la

Koo i $a$ i'au, a paa no.:II ${ }^{44}$

The Lyons translation of the earlier version of "I Left It All With Jesus" establishes that he had access to music from the gospel hymnbooks of Bliss and Sankey. The tune for "Hawai'i Aloha" by McGranahan came from a subsequent collaboration by Sankey with McGranahan and Stebbins after the death of Bliss-Gospel Hymns No. 4, published in 1881. A words-only edition of Gospel Hymns No. 4 was published two years earlier, in $1879,{ }^{45}$ and Lyons most likely would 
have had access to the music that would have accompanied the version. The ninety translated hymns in Na Himeni Euanelio also demonstrate the ease with which Lyons wrote Hawaiian words set to existing gospel music. The most likely date for the composition of the words of "Hawai'i Aloha," therefore, falls after the publication of Gospel Hymns, No. 4 (Words Only) in 1879, when the music was first available, and before the death of Lyons on October 6, 1886. Since Lyons had already translated the shorter version of "I Left It All With Jesus" into Hawaiian in Na Himeni Euanelio: I Unuhiia e L. Laiana Mamuli o Moody me Sankey, etc. (1886), he may have avoided making a translation of a slightly longer version of basically the same lyrics. He instead wrote original Hawaiian words for what would otherwise have been an orphan tune. Such a late date would also help explain why "Hawai'i Aloha" was never included in hymn collections published by Lyons. The first Hawaiian hymnal printed after the death of Lyons, the 1902 edition of Leo Hoonani, included three Hawaiian hymns with music by McGranahan, but none of them are "Hawai“i Aloha." The translations by Joseph Kalaina of "The Banner of the Cross," Lorenzo Lyons of "The Crowning Day" and Dr. Charles M. Hyde of "I Know Whom I Have Believed," appear with music attributed to James McGranahan. The Hawaiian Evangelical Association, successor to the Hawaiian Mission, requested and received authorization to use the three tunes from James McGranahan himself (Figure 6). Like "Hawai'i Aloha," the hymn, "The Crowning Day," or "Haaleleia 'la Iesu," combined the Hawaiian words by Lorenzo Lyons and music published in 1881 by James McGranahan. The Hawaiian words alone had appeared earlier as hymn 53 in Buke III of the 1886 edition of Na Himeni Euanelio: $\mathrm{Na}$ Buke I, 2, Me 3, I Huiia, with the tune given as G.H. 416, which refers hymn 416 in the 1883 edition of Gospel Hymns Consolidated Embracing Volumes No. I, 2, 3 and 4, Without Duplicates, for Use in Gospel Meetings and Other Religious Services. Unlike “The Crowning Day," however, publishers still leave off the name of James McGranahan on versions of "Hawai'i Aloha."

\section{Still Missing}

Despite knowledge of McGranahan's role dating to 1886 , and published credit to him as composer in hymnals as recently as 1999, the 


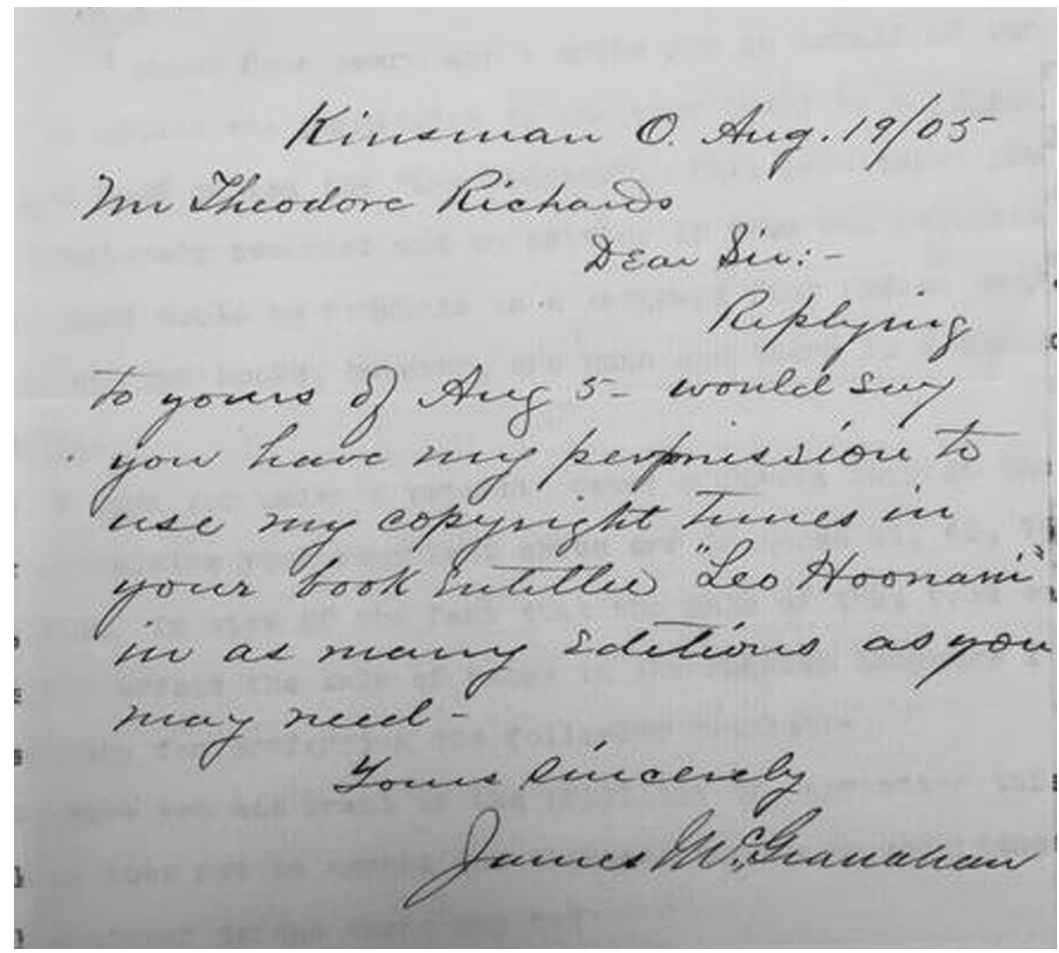

Figure 6. The signature of James McGranahan closed his letter of August 19, 1905, granting permission to use his music for three hymns that appeared in the subsequent reprints of 1902 edition of Leo Hoonani. Theodore Richards had edited the volume. McGranahan would die in Kinsman, Ohio, within two years of writing the letter. Courtesy Hawaiian Mission Children's Society. Photograph by John Barker, curator of the archives of the society, who discovered the letter.

name of the man who wrote the music for "Hawai"i Aloha" has been omitted routinely from recent publications. The 2007 issue of Honolulu Magazine ranked "Hawai"i Aloha" as number 6 in its "5o Greatest Songs of Hawaii” but only listed the tune title, "I Left It All With Jesus," and not the name of its American composer. John Heckathorn in a 2009 blog for Hawaii Magazine, titled "The song you need to know in Hawaii," credits only Lyons for "Hawai'i Aloha" in an answer to a reader query. ${ }^{46}$ So, today, even with the overwhelming popularity of "Hawai'i Aloha," the composer of the music, James McGranahan, 
often does not get the proper recognition for his contribution to the iconic Hawaiian anthem.

\section{Notes}

${ }^{1}$ Naturalization record for Lorenzo Lyons, June 6, 1851, Index to Naturalization Record Book, For Individuals Naturalized by the Minister of the Interior of the Hawaiian Islands, I844-I 894, (Honolulu: AH, n.d.) n.p. [Series 234, vol. K, 8,] AH.

${ }^{2}$ Lorenzo Lyons, 29th Annual Report of Waimea Mission Station (1861), 21-22 HMCS.

${ }^{3}$ Samuel Hoyt Elbert, Na Mele O Hawaii Nei: Ior Hawaiian Songs (Honolulu: University of Hawai'i Press, 1970) $4^{2}$.

${ }^{4} \mathrm{Na}$ Mele o Ziona (Honolulu: L.D.S. Hawaiian Mission, 1924) [ii].

${ }^{5}$ Ethel Damon, "Na Himeni Hawaii," F, May 1935, 506.

${ }^{6}$ Ka Nupepa Kuokoa, Dec. 11, 1886, 4 .

${ }^{7}$ Ira D. Sankey, James McGranahan, and George C. Stebbins, eds., Gospel Hymns No. 4 (Chicago: Biglow \& Main Co., 1881) 20-21.

${ }^{8}$ Gospel Hymns Nos. I to 6 Complete (Without Duplicates) (Chicago: Biglow \& Main Co., 1894) 216.

${ }^{9}$ First Truths; or, Lessons and Hymns for Christian Children (London: Society for Promoting Christian Knowledge, 1843) 102.

${ }^{10}$ I Left It All with Jesus, and Other Poems (London: John F. Shaw \& Co., [1875]) [7].

${ }^{11}$ Ethel Damon, "Na Himeni Hawaii," F, May 1935, 5 o6.

12 Ethel M. Damon, Na Himeni Hawaii: A Record of Hymns in the Hawaiian Language $(F$, Dec.12, 1935) 27.

${ }^{13}$ Anna B. Tucker and Jane Lathrop Winne, Simple Songs for Little Singers (Honolulu: Honolulu Star Bulletin, 1931) 7 .

14 Tucker and Winne, Simple Songs for Little Singers 142-143.

15 Missionary Album: Portraits and Biographical Sketches of the American Protestant Missionaries to the Hawaiian Islands (Honolulu, Hawai' $\mathrm{i}$ : The Hawaiian Mission Children's Society, 1969) 145.

${ }^{16}$ Leo Hoonani Hou (Honolulu: Hawaiian Evangelical Association of Congregational Christian Churches, 1953) 239.

17 George S. Kanahele, Hawaiian Music and Musicians (Honolulu: University of Hawai'i Press, 1979) 107.

${ }^{18}$ John Berger, "Hawai'i Aloha (Beloved Hawaii): Stand and Hold Hands for this Perennial Favorite," Hawaii Magazine, vol. 13, no. 5 (Sept.-Oct. 1996) 71.

19 State of Hawaii, Department of Education, Office of Instructional Services, General Education Branch, Hawaiian Studies Curriculum Guide (Honolulu, January $\left.19^{8} 5\right), 4^{8}$.

${ }^{20}$ Ethel M. Damon, "Memories of Father Lyons," F, June 1932, 424.

${ }_{21}$ Tucker and Winne, Simple Songs for Little Singers 143.

22 Tucker and Winne, Simple Songs for Little Singers 8.

${ }^{23}$ Elbert, Nā Mele O Hawai ‘i Nei: Io I Hawaiian Songs 42. 
${ }^{24} \mathrm{Na}$ Himeni Haipule Hawaii (Honolulu: Hawaii Conference, United Church of Christ, 1972) 3 .

${ }^{25}$ E. S. Handy, E. G. Handy, Mary Kawena Pukui, Native Planters in Old Hawaii: Their Life, Lore, and Environment (Honolulu: Bishop Museum Press, 1972) 289.

${ }_{26}$ Tucker and Winne, Simple Songs for Little Singers 143.

${ }^{27}$ George S. Kanahele, Hawaiian Music and Musicians (Honolulu: University of Hawai'i Press, 1979) 108.

${ }^{28}$ Kanahele, Hawaiian Music and Musicians 108.

${ }^{29}$ John Berger and George Sanford Kanahele, Hawaiian Music and Musicians (Honolulu: Mutual Publishing, 2012) 265.

${ }^{30}$ John Berger, "Hawai'i Aloha (Beloved Hawaii)," Sept.-Oct. 1996, 71.

31 Emma Lyons Doyle, Makua Laiana: The Story of Lorenzo Lyons (Honolulu: Honolulu Star-Bulletin, 1945) 256-257.

${ }^{32}$ Emma Lyons Doyle, Makua Laiana: The Story of Lorenzo Lyons (Honolulu: Honolulu Star-Bulletin, 1953) 268-269.

33 "Departure of Hawaiian Missionaries," PCA, July 10, 1869, 3.

${ }^{34}$ Lorenzo Lyons, Ka Buke Himeni Hawaii (New York: Paiia e Ko Amerika Ahahui Teraka, 1872) 535 .

35 Carol Wilcox, ed., He Mele Aloha (Honolulu: 'Oli 'Oli Productions, 2003) 45.

${ }^{36}$ Lorenzo Lyons, Waimea Mission Report (1861) 1 75, HMCS.

37 Sixty-Seventh Annual Report of the Trustees of the New York Public Library for the Year I 884 (Albany: Weed Parsons and Co., 1885) 85 .

38 Missionary Album 145.

39 Missionary Album 145.

${ }^{40}$ Kathie Fry, "History of the Song "Hawaii Aloha," http://www.hawaiianmusic history.com/songs/hawaii-aloha-history.htm.

${ }^{41}$ Kahae Thomas, "History of Hawai'i Aloha," http://www.cappedhawaii.com/ \#!History-of-Hawaii-Aloha/c1r22/55d8b6agocf2 1 fd94cc26a56 (Aug. 22, 2015)

42 Jan E. Hanohano Dill, "Reflections on Days Gone By," https://atlowtide.com/ 2015/12/21/refections-on-days-gone-by/, December 21, 2015.

${ }^{43}$ Ethel Damon, "Na Himeni Hawaii," F, April 1935, 490.

${ }^{44}$ Philip Paul Bliss and Ira David Sankey, Na Himeni Euanelio, Buke III, i Unuhiia e L. Laiana, Mamuli o Moody Me Sankey (Honolulu: Hoopukaia e Ka Papa Hawaii, 1886) $26,27$.

45 Sixty-Seventh Annual Report of the Trustees of the New York Public Library for the Year I 884 (Albany: Weed Parsons and Co., 1885) 85 .

${ }^{46}$ http://www.hawaiimagazine.com/blogs/hawaii_today/2009/5/14/hawaii _aloha_lyrics, May 14, 2009. 
